\title{
Prevalence of antibodies to Aujeszky's disease virus in wild boar in Poland, between 2011 and 2014: a retrospective study
}

\author{
Andrzej Lipowski, Anna Szczotka-Bochniarz, Zygmunt Pejsak \\ Department of Swine Diseases, \\ National Veterinary Research Institute, 24-100 Pulawy, Poland \\ anna.szczotka@piwet.pulawy.pl
}

Received: May 19, $2017 \quad$ Accepted: November 2, 2017

\begin{abstract}
Introduction: Aujeszky's disease virus (ADV) infects a wide range of animals, including members of the Suidae family, i.e. domestic and wild pigs, as well as wild boar. Since wild boar are a potential ADV reservoir and a source of infection for domestic pigs, the aim of the study was to evaluate ADV antibody prevalence in the Polish wild boar population, during the years 2011 to 2014. Material and Methods: Wild boar blood samples were collected during three consecutive hunting seasons; i.e. 2011/2012, 2012/2013, and 2013/2014, and tested for ADV antibodies by ELISA. Results: ADV antibodies were detected in samples from all tested voivodships. The average seroprevalence reached $32.2 \%$. Seroprevalence, over the examined hunting seasons, was $27.4 \%$ in $2011 / 2012,32.4 \%$ in $2012 / 2013$, and $35.5 \%$ in 2013/2014. The highest percentage of seroreagents was detected in four voivodships, situated along the western border of Poland, i.e. Zachodnio-Pomorskie (ZP), Lubuskie (LB), Dolnośląskie (DS), and Opolskie (OP). This area is positively correlated with the highest density of the wild boar population and the highest wild boar hunting bag. Conclusion: The results of this study confirm that the wild boar population may still pose a threat to domestic pigs, which is of special importance at the final stage of Aujeszky's disease eradication programme in Poland.
\end{abstract}

Keywords: wild boar, Aujeszky's disease, antibodies, disease surveillance, Poland.

\section{Introduction}

Aujeszky's disease (AD) is caused by Suid herpesvirus 1 (SuHV1, syn. Aujeszky's disease virus ADV or pseudorabies virus - PRV) which belongs to the Herpesviridae family, subfamily Alphaherpesvirinae, genus Varicellovirus (9). The only natural hosts for ADV are members of the Suidae family; i.e. domestic pigs (DP) as well as wild swine, including European wild boar (WB), and feral swine, typical in the USA and some regions of Europe (21). Considering domestic pigs, the main reservoir and source of ADV are pigs during the incubation period, diseased and latently infected (21). Aujeszky's disease represents one of the most economically important diseases in domestic pigs, causing substantial direct and indirect losses in the pig industry. Direct losses are due to reproductive failures, the mortality rate reaching $100 \%$ in piglets up to 14 days of life, and growth retardation resulting in a prolonged fattening period. Indirect losses, observed in weaning and finishing pigs, are related to secondary bacterial infections and additional costs of medication (21). Also, the appearance of the disease causes serious restrictions or even the prohibition of international pig movement and trade $(5,19)$.

As mentioned above, wild swine are equally susceptible to ADV infection as domestic ones. Therefore, these wild animals should be considered as a potential ADV reservoir and source of infection for domestic pigs (21). This threat is especially important in countries, regions, or pig holdings free from ADV and, therefore, $\mathrm{AD}$ monitoring among wild swine is strongly advisable $(25,34)$. This is particularly important in Poland, where the $\mathrm{AD}$ eradication programme has been carried out since 2008 (22). Therefore, the object of this study was to evaluate the antibody prevalence of ADV in the Polish wild boar population, during the years 2011 to 2014 . 


\section{Material and Methods}

Sera. A total of 27,548 WB blood samples from the whole territory of Poland, collected and examined between 2011 and 2014, under the auspices of classical swine fever monitoring by the Regional Veterinary Diagnostic Laboratories of the Veterinary Inspectorate, were delivered to the Department of Swine Diseases of the National Veterinary Research Institute in Pulawy. The blood samples were collected during three consecutive hunting seasons; i.e. 2011/2012, 2012/2013, and 2013/2014. From the first hunting season, 7,078 samples were received and 7,021 (99.2\%) of them were tested. In the next hunting season, a total of 10,155 blood samples were delivered, but only 10,079 (99.3\%) of them were tested. In the last hunting season, 10,315 blood samples were delivered and only 10,163 (98.5\%) were analysed. Limitations of $0.8 \%, 0.7 \%$, and $1.5 \%$, respectively, resulted mostly from the poor quality of the samples (haemolysis and autolysis) which yielded them unsuitable for ELISA testing.

ELISA. An ELISA Pseudorabies Virus gpI Antibody Test Kit (IDEXX PRV/ADV gI, IDEXX Laboratories, USA) was used, according to manufacturer's instructions.

\section{Results}

The results of the examination of WB blood samples, collected during the three consecutive hunting seasons are shown in Table 1 and Figs 1, 2, and 3, respectively.

Regarding hunting season 2011/2012, data indicated that serologically ADV positive WB were detected in all 15 voivodships examined (Table 1 and Fig. 1). No WB blood samples were received from Zachodnio-Pomorskie. The highest percentage of seropositive WB was found in Opolskie - 44.2\%, followed by Dolnośląskie - 38.1\%, Lubuskie $31.3 \%$, Podlaskie - 30.2\% and Wielkopolskie $29.9 \%$. The highest percentages of ADV seropositive WB were detected mainly in three western voivodships (Opolskie, Dolnośląskie, and Lubuskie). In the remaining voivodships, the percentage of WB infected with ADV ranged from 7.0\% (Świętokrzyskie) to $28.5 \%$ (Kujawsko-Pomorskie). An average percentage of ADV seroreagents detected in the hunting season $2011 / 2012$ was $27.4 \%$ (Table 1).

Table 1. The results of ADV antibody detection in WB between 2011 and 2014

\begin{tabular}{|c|c|c|c|c|c|c|c|c|}
\hline \multirow{4}{*}{ Voivodship (abbr.)* } & \multicolumn{6}{|c|}{ Hunting season } & \multirow{2}{*}{\multicolumn{2}{|c|}{ Total }} \\
\hline & \multirow{2}{*}{\multicolumn{2}{|c|}{$\begin{array}{l}2011 / 2012 \\
\text { No. of samples }\end{array}$}} & \multirow{2}{*}{\multicolumn{2}{|c|}{$\begin{array}{l}2012 / 2013 \\
\text { No. of samples }\end{array}$}} & \multicolumn{2}{|c|}{$2013 / 2014$} & & \\
\hline & & & & & No. of $\mathrm{s}$ & mples & No. of $\mathrm{s}$ & mples \\
\hline & tested & positive $(\%)$ & tested & positive $(\%)$ & tested & positive (\%) & tested & positive $(\%)$ \\
\hline Dolnośląskie (DS) & 663 & $253(8.1 \%)$ & 1,026 & $411(40.1 \%)$ & 897 & $354(39.5 \%)$ & 2,586 & $1,018(39.4 \%)$ \\
\hline Kujawsko-Pomorskie (KP) & 428 & $122(28.5 \%)$ & 827 & $250(30.2 \%)$ & 662 & $225(34.0 \%)$ & 1,917 & $597(31.1 \%)$ \\
\hline Lubelskie (LU) & 851 & $230(27.0 \%)$ & 390 & $110(28.2 \%)$ & 877 & $361(41.1 \%)$ & 2,118 & $701(33.1 \%)$ \\
\hline Lubuskie (LB) & 553 & $173(31.3 \%)$ & 931 & $274(29.4 \%)$ & 1,006 & $311(30.9 \%)$ & 2,490 & $758(30.4 \%)$ \\
\hline Łódzkie (LD) & 280 & $75(26.8 \%)$ & 297 & $92(31.0 \%)$ & 192 & $43(22.4 \%)$ & 769 & $210(27.3 \%)$ \\
\hline Małopolskie (MA) & 210 & $37(17.6 \%)$ & 296 & $67(22.6 \%)$ & 114 & $59(27.6 \%)$ & 620 & $163(26.3 \%)$ \\
\hline Mazowieckie (MZ) & 430 & $111(25.8 \%)$ & 161 & $58(36.0 \%)$ & 512 & $166(32.4 \%)$ & 1,103 & $335(30.4 \%)$ \\
\hline Opolskie (OP) & 285 & $126(44.2 \%)$ & 495 & $204(41.2 \%)$ & 312 & $129(41.4 \%)$ & 1,092 & $459(42.0 \%)$ \\
\hline Podkarpackie (PK) & 343 & $69(20.1 \%)$ & 489 & $120(24.5 \%)$ & 509 & $138(27.1 \%)$ & 1,341 & $327(24.4 \%)$ \\
\hline Podlaskie (PD) & 610 & $184(30.2 \%)$ & 186 & $41(22.0 \%)$ & 595 & $229(38.5 \%)$ & 1,391 & $454(32.7 \%)$ \\
\hline Pomorskie (PM) & 949 & $205(21.6 \%)$ & 1,167 & $289(24.8 \%)$ & 1,171 & $389(33.2 \%)$ & 3,287 & $883(26.9 \%)$ \\
\hline Śląskie (SL) & 306 & $76(24.8 \%)$ & 525 & $105(20.0 \%)$ & 389 & $116(29.1 \%)$ & 1,220 & $297(24.3 \%)$ \\
\hline Świętokrzyskie (SK) & 85 & $6(7.0 \%)$ & 122 & $11(9.0 \%)$ & 151 & $30(33.1 \%)$ & 358 & $47(13.1 \%)$ \\
\hline Warmińsko-Mazurskie (WN) & 884 & $211(23.9 \%)$ & 561 & $150(26.7 \%)$ & 361 & $112(31.0 \%)$ & 1,806 & $473(26.2 \%)$ \\
\hline Wielkopolskie (WP) & 144 & $43(29.9 \%)$ & 345 & $115(33.3 \%)$ & 4,45 & $134(30.1 \%)$ & 934 & $292(31.3 \%)$ \\
\hline Zachodnio-Pomorskie (ZP) & - & - & 2,261 & $966(42.7 \%)$ & 1,861 & $794(42.7)$ & 4,122 & $1,760(42.7 \%)$ \\
\hline Total & 7,021 & $1,921(27.4 \%)$ & 10,079 & $3,263(32.4 \%)$ & 10,163 & $3,610(35.5 \%)$ & 27,154 & $8,774(32.3 \%)$ \\
\hline
\end{tabular}

* - according to the Toponymic Guidelines of Poland for Map Editors and Other Users, $4^{\text {th }}$ revised edition, Head Office of Geodesy and Cartography, Warszawa 2010 


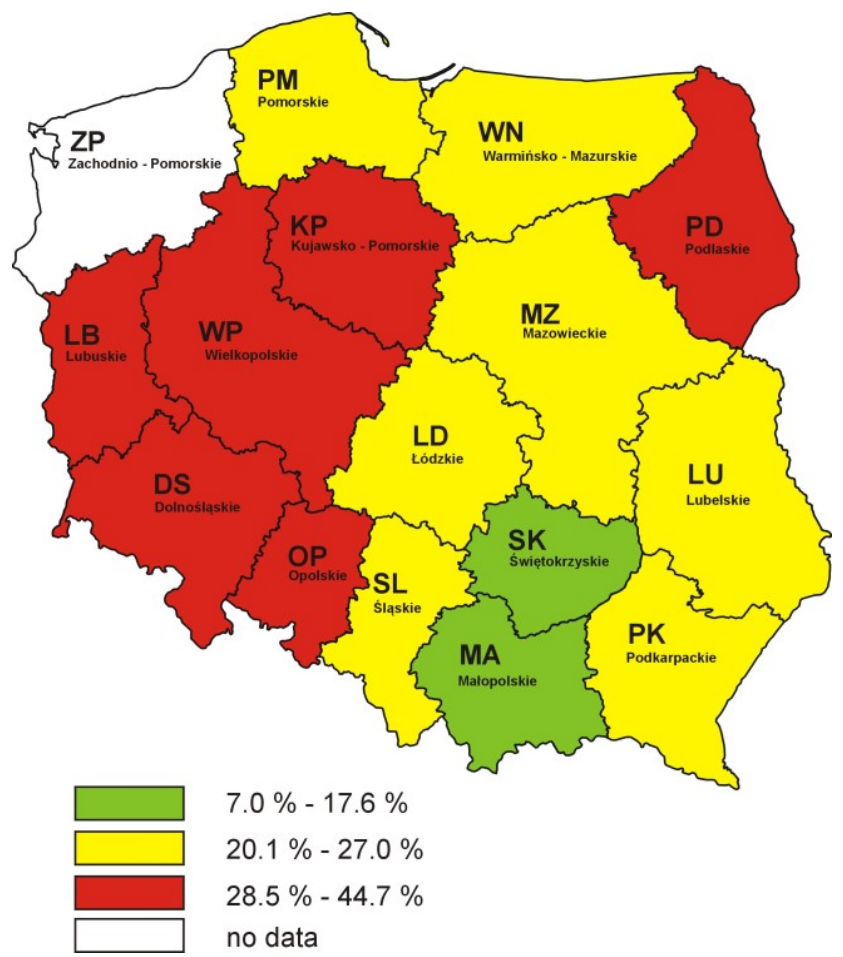

Fig. 1. ADV seroprevalence in WB in Poland, in the hunting season $2011 / 2012$

In the following 2012/2013 hunting season, ADV seroreagents were present in all 16 Polish voivodships (Table 1 and Fig. 2). The highest percentage of ADV seropositive WB was found in Zachodnio-Pomorskie (42.7\%), followed by Opolskie (41.2\%), Dolnośląskie (40.1\%), Mazowieckie (36.0\%), and Wielkopolskie (33.3\%). In Łódzkie, Kujawsko-Pomorskie, Lubuskie, Lubelskie, and Warmińsko-Mazurskie the percentage of seroreagents was $31.0 \%, 30.2 \%, 29.4 \%, 28.2 \%$, and $26.7 \%$, respectively. In the remaining voivodships, the percentage of WB seropositive for ADV ranged from $9.0 \%$ (Świętokrzyskie) to $24.8 \%$ (Pomorskie). An average percentage of ADV seropositive WB detected in the hunting season 2012/2013 was $32.4 \%$ (Table 1 ).

The results of the examination of WB blood samples collected in the hunting season 2013/2014 indicated that ADV seroreagents were detected in all 16 voivodships (Table 1 and Fig. 3). The highest percentage of WB infected with ADV were found in Zachodnio-Pomorskie (42.7\%) and in Opolskie (41.4\%). The percentages of ADV seroreagents in Lubelskie, Dolnośląskie, Podlaskie, KujawskoPomorskie, Pomorskie, Świętokrzyskie, Mazowieckie, and Warmińsko-Mazurskie were 41.1\%, 39.5\%, 38.5\%, $34.0 \%, 33.2 \%, 33.1 \%, 32.4 \%$, and $31.0 \%$, respectively. In Lubuskie, Wielkopolskie, Śląskie, Małopolskie, Podkarpackie, and Łódzkie, they were 30.9\%, 30.1\%, $29.1 \%, 27.6 \%, 27.1 \%$, and $22.4 \%$, respectively. The average percentage of seropositive WB detected in hunting season $2013 / 2014$ was $35.5 \%$ (Table 1).

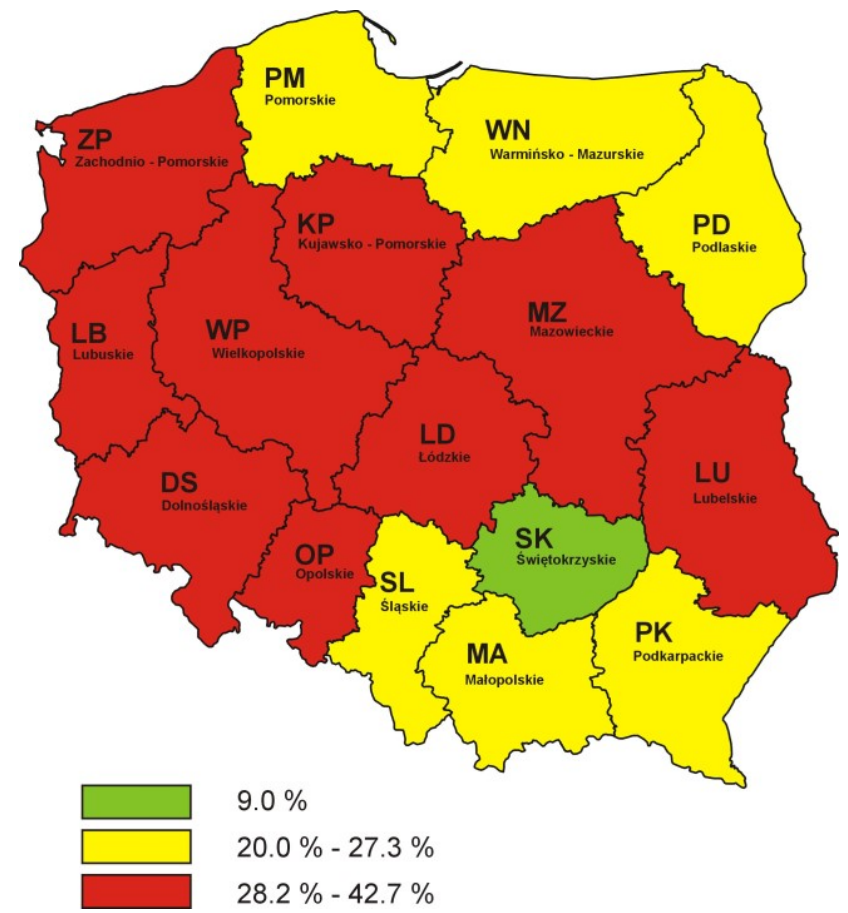

Fig. 2. ADV seroprevalence in $\mathrm{WB}$ in Poland, in the hunting season $2012 / 2013$

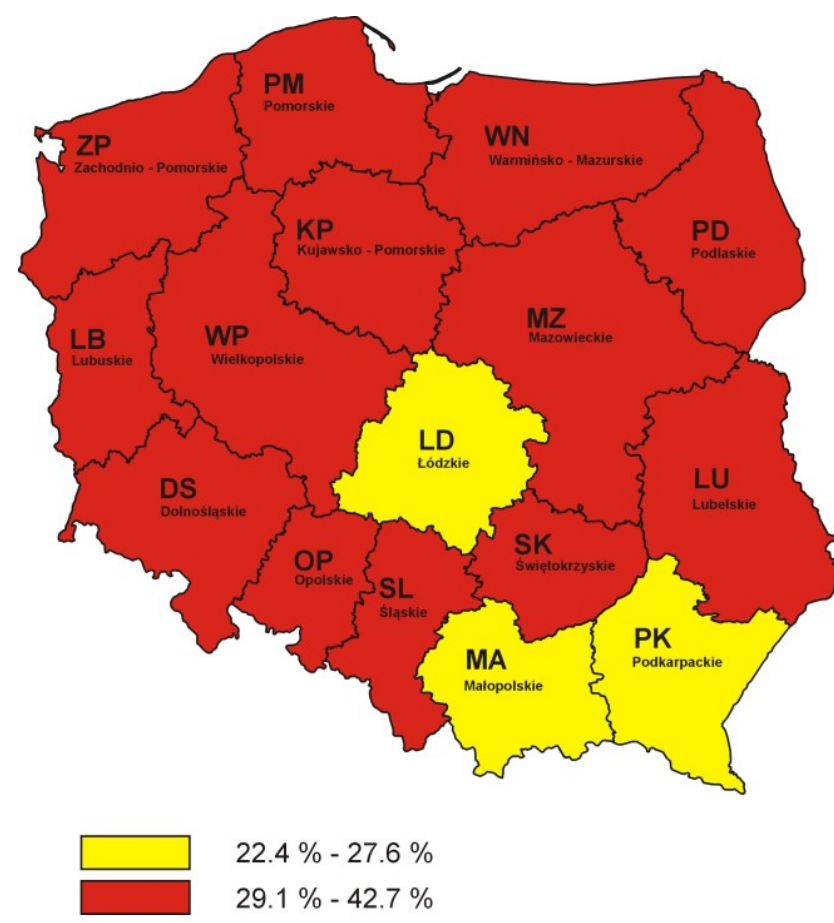

Fig. 3. $\mathrm{ADV}$ seroprevalence in $\mathrm{WB}$ in Poland, in hunting season $2013 / 2014$

Total results of the examination of WB blood samples collected during the three consecutive hunting seasons are summarised in Table 1 and Fig. 4. An average percentage of ADV seropositive WB in 
a hunting season amounted to $32.2 \%$ and ranged from $13.1 \%$ (Świętokrzyskie) to $42.7 \%$ (ZachodnioPomorskie).

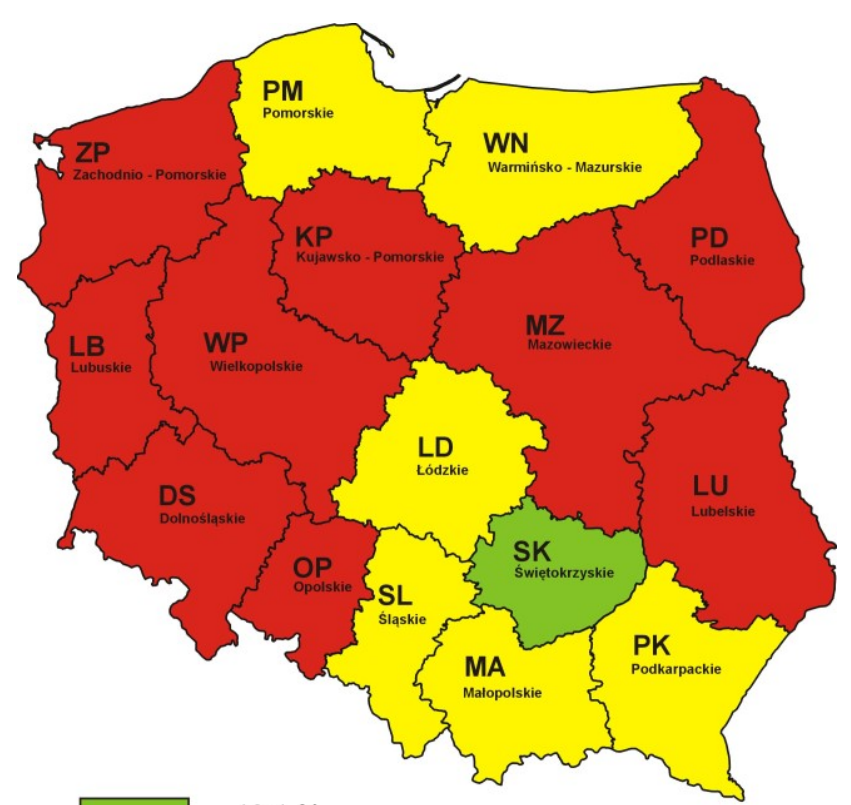

$13.1 \%$

$24.3 \%-27.3 \%$

$30.4 \%-42.7 \%$

Fig. 4. ADV seroprevalence in $\mathrm{WB}$ in Poland, between 2011 and 2014

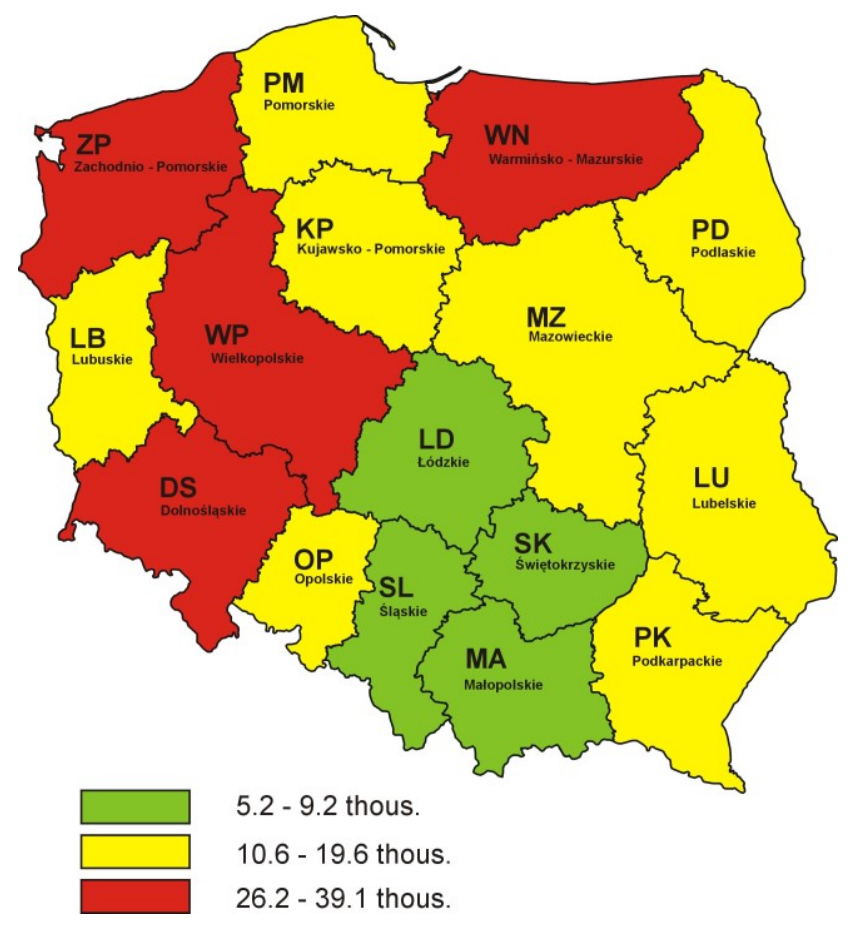

Fig. 5. Wild boar population (approx.) in Poland, between 2011 and 2014

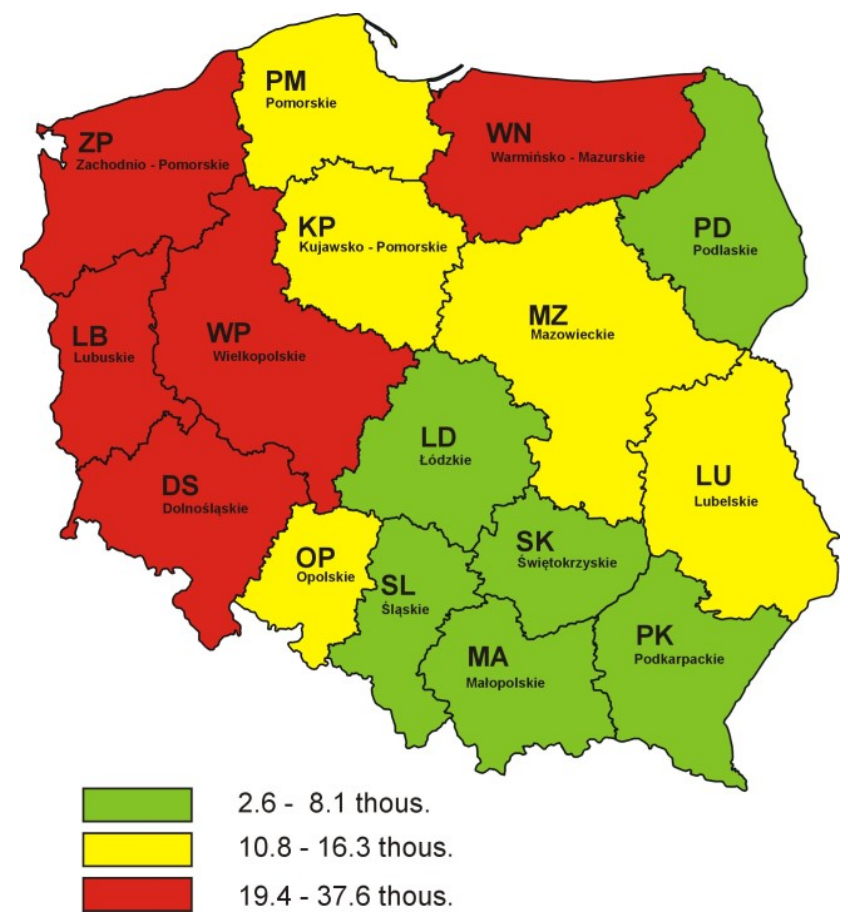

Fig. 6. Wild boar hunting bag (mean) in Poland, between 2011 and 2014

\section{Discussion}

The results of the present study should be compared to the results of a similar investigation conducted in Poland during the years 1997 to 2000 (20). This previous study revealed an average of $14.52 \%(12.9 \%-18.6 \%)$ seropositive WB. Such animals were detected in 15 out of the 16 voivodships examined (20). The comparison of these results with the current ones, presented in this paper, reveals more than a double increase in the percentage of ADV seroreagents among WB, detected in all 16 voivodships, which indicates that $A D V$ infection is endemic in the WB population of Poland.

The data concerning seroprevalence of ADV seroreagents show the intensive rate of infection with this virus, mostly in the western voivodships. Interestingly, these results correlate well with WB population density (Fig. 5) and WB hunting bag (Fig. 6).

The aforementioned increase in ADV seroprevalence is most likely connected with an increase in the WB population (25). During the last 14 years the population of WB in Poland has increased by about $140.6 \%$, from 118,300 in the $2000 / 2001$ hunting season to 284,600 in the $2013 / 2014$ hunting season (12). At the same time, hunting bag increased by about $160.2 \%$, from 93,000 in the $2000 / 2001$ hunting season to 242,000 in the $2013 / 2014$ hunting season (12). WB population increase could be explained by several reasons, e.g. climate change (shorter and milder winters), modifications to agricultural land use, and supplementary feeding during winter. Also, year-to-year intensification of hunting pressure has had an influence on the increased, uncontrolled reproduction of WB 
(i.e. 2-3 litters per year) observed not only among multiparous sows, but also among one-year-old gilts (25).

The high ADV infection rate of WB determined during the surveyed hunting seasons in four voivodships situated along the western border of Poland, i.e. in Zachodnio-Pomorskie (ZP), Lubuskie (LB), Dolnośląskie (DS), and Opolskie (OP), should be underlined. The high percentage of ADV seropositive WB detected in the 2011/2012 hunting season in these voivodships was confirmed by the results of the examination of WB blood samples collected in the following hunting seasons of 2012/2013 and 2013/2014 (Table 1).

Interestingly, in the hunting season 2012/2013, a higher percentage of ADV seroreagents, in the range of $1.2 \%-10.2 \%$, was detected in 12 voivodships, which resulted in a 5\% higher average seroprevalence of ADV, in comparison to the 2011/2012 hunting season (Table 1). A slight decrease in $1.9 \%-8.2 \%$ of ADV seroprevalence was only found in four voivodships (Table 1).

However, alarmingly, in the hunting season 2013/2014, a significant increase in ADV seropositive WB was observed in six voivodships, compared to the previous hunting season. The aforementioned increase was detected in Świętokrzyskie (SK) $(+24.1 \%)$ and then in Śląskie (SL) $(+19.1 \%)$ Podlaskie (PD) $(+16.5 \%)$, Lubelskie (LU) (+12.9\%), and Pomorskie (PM) (+8.4\%). Moreover, a slight increase in ADV seroreagents $(0.2 \%$ to $5.0 \%$.) was detected in six more voivodships. Finally, in Zachodnio-Pomorskie (ZP) the rate of infection was the same as in the previous hunting season, whereas a decrease in ADV seroprevalence, ranging from $0.6 \%$ to $8.6 \%$, was found in the four remaining voivodships.

The problem of an exploding increase in the WB population has been observed in Europe since the 1950s, referring to, among other places, France (1), Spain (3), Switzerland (18), Italy (25), Germany (27), Croatia (29), Czech Republic (35), and Slovenia $(39,43)$. A similar trend has been observed in the USA (6) where, over the last 10 years, the feral swine population has increased four-fold and is already distributed across 39 of the 50 states $(25)$.

The endemic prevalence of $\mathrm{AD}$ in $\mathrm{WB}$, as observed in Poland, after two series of investigations, performed at 15 year intervals $(20,40)$ was also found in other European countries, as well as in the USA (25). Largescale investigations conducted in Germany over many years have allowed the detection of $0.4 \%$ to $16.5 \% \mathrm{ADV}$ seropositive $\mathrm{WB}$ on average, depending on the region or "land" examined $(10,25,27)$. Pannwitz et al. (27) indicate that the percentage of WB infected with ADV along Germany's eastern border with Poland, can exceed $45 \%$. These estimates have been made on the basis of observations carried out since the 1990s, showing an increasing seroprevalence, ranging between $20 \%$ and $30 \%$. The cited authors suggest that the reason for high $\mathrm{AD}$ prevalence could be the migration of ADV-infected
WB across the bordering Oder River, in both directions; i.e. from Germany to Poland and back to Germany (27). In fact, there was no investigation of WB regarding ADV seroprevalence along the Polish - German border before 1997. However, the results of the present study show a high percentage of ADV infected $\mathrm{WB}$, averaging from $30.4 \%$ in Lubuskie (LB) to $42.7 \%$ in ZachodnioPomorskie (ZP) (Table 1 and Fig. 4).

Infections of $\mathrm{WB}$ with $\mathrm{ADV}$ in East Germany appear to be dynamic, over time, with variance of the percentage of seroreagents and areas of their prevalence. The disappearance of $\mathrm{AD}$ in some areas and its movement into new, non-infected areas was also observed (41). The so-called "pockets of infection" were found to have moved in the western direction, at a distance of about $3.3 \mathrm{~km}$ per year (41). A similar conclusion was drawn by Denzin et al. (10) who detected an average of $4.47 \%$ ADV seropositive WB. Furthermore, in the years 2009 to 2011 , the number of such animals doubled, reaching 9.05\% (10).

In Spain, different serological studies carried out in various regions, revealed from $0.8 \%$ to $60.6 \%$ of seropositive $\mathrm{WB}(3,32,33,45)$. Interestingly, ADV seroprevalence among the free-living WB ranged from $21.4 \%$ to $42.4 \%$, and among WB living in fenced areas the average seroprevalence was $66.1 \%(32,45)$.

A similar comparison of the $\mathrm{ADV}$ infection rate among WB living in free and/or in fenced areas was performed in Austria. The percentage of seroreagents during the years 2010 to 2011 among the free-living WB amounted to $37.9 \%$, and among the WB in fenced areas it was $69.6 \%$ (37), with an average of $55.2 \%$ (37). During the years 2011 to 2012, the percentage of WB infected with $\mathrm{ADV}$ was estimated at $22.8 \%$ (38).

Studies performed in former Yugoslavia during the 1980 s revealed the percentage of ADV-infected WB from fenced areas to be $74.4 \%$, and $26.8 \%$ from open areas (13).

The comparison of the aforementioned data from Spain, Austria, and former Yugoslavia indicates that ADV circulates very intensively among WB held in pens, resulting in a higher seroprevalence than among free-roaming $\mathrm{WB}$, with a much lower rate of $\mathrm{ADV}$ infection.

In Croatia, during the winter 1999 hunting season, the rate of ADV seropositive WB was 54.4\% (47). Later, Roic et al. (29) found an average seroprevalence of $38.5 \%$ during the years 2005 to 2010 . During 2005 and $2006,28.1 \%$ of seroreagents were detected and during 2009 and 2010 the number doubled, reaching $57.4 \%$. In Slovenia, in the period 2003 to 2004, the percentage of ADV-infected WB reached $26 \%-31 \%(43,44)$. Later, in the 2010/2011 hunting season, the seroprevalence increased to $45.1 \%$ (39).

In Italy, data collected in various studies on the WB population indicated that $\mathrm{ADV}$ seroprevalence ranged from $20.0 \%$ to $51.0 \%(17,23)$.

In France, the first investigation on WB involving AD was undertaken in 1979 and no seroreagents were 
found (2). The next ADV serosurvey, carried out during the years 1991 to 1998 , revealed approximately $3.3 \%$ of seroreagents among free-living $\mathrm{WB}$, and $1.18 \%$ among WB held in fenced areas (1). The latter result is significantly lower than that detected in the following years in Austria or in Spain $(32,37,45)$. However, taking into account the dynamics of ADV spread among $\mathrm{WB}$, together with the increasing population of these animals over recent decades, the cited results reflect the actual situation in France, during the period 1991 to 1998 (1). An investigation carried out in France between 2000 and 2004 revealed a much higher percentage of ADV seropositive WB, reaching 53\% (25).

In the Netherlands, the first serological investigation of $\mathrm{WB}$ infected with $\mathrm{ADV}$, undertaken in 1994 , in only one of the country's regions, revealed $2.6 \%$ seroreagents (8). The next ADV serosurvey carried out during the period between 1996 and 1999 indicated an unequivocal lack of ADV infections among the WB population (11).

In Belgium, neighbouring Germany and the Netherlands, serological screening, conducted during 2004 and 2005 detected $15 \%-22 \%$ of ADV seropositive WB (25). In Switzerland, the percentage of seroreagents ranged from $2.4 \%$ to $6.9 \%$, depending on the region investigated. In this country, an increasing population of WB was also observed (18). A similar trend was found in the Czech Republic, where the mean percentage of ADV seroreagents based on the results of a serological investigation carried out between 2004 and 2005, was estimated at $29.9 \%$ (35). In Russia, a similar serosurvey has shown $32.5 \%-39.5 \%$ of ADV seropositive WB, depending on the region of investigation (25).

As appears from the aforementioned data, in those European countries where serological investigations targeting ADV seroprevalence among WB populations have been performed, the occurrence of WB infected with ADV has been confirmed, although in different percentages.

A similar problem to that observed in Europe also exists in the USA. An investigation dedicated to ADV infection among feral swine started in the mid-1970s and has continued up until now $(6,7,14,15,28,30,31,36$, $42,46)$. The percentage of ADV seropositive feral swine differed between years and depended, among other things, on the state or region of investigation. It was therefore difficult to estimate ADV seroprevalence for the whole country. These studies were performed mainly in the southern or south-eastern states of the USA, where the feral swine population seems to be the biggest. As a consequence, it was found that the percentage of ADV seroreagents among the tested animals could be as high as $100 \%$ (7). On the other hand, wide-scale serological investigations carried out in 35 states, where feral swine are present, allowed the detection of $18 \%$ of animals infected with ADV in 25 states (28). Moreover, based on many years of serosurveys, it was found that ADV could have been endemic in certain regions for as long as 32 years $(7,28)$.

Wild swine infected with ADV were also detected in Brazil, Tunisia, and Iran. The percentage of seroreagents amounted to $25.2 \%-100 \%, 63 \%$, and $42.7 \%$, respectively $(4,25)$. Investigations in South Korea allowed the detection of $35.7 \%$ of $\mathrm{ADV}$ seropositive WB (16).

The presented results, originating from different European countries, the USA, Brasil, Tunisia, and Iran, indicate a high percentage of $\mathrm{WB}$ and/or feral swine infected with ADV, repeatedly higher than the values detected in Poland between 2011 and 2014. Interestingly, the results of an $\mathrm{ADV}$ serosurvey conducted in our country between 1997 and 2000 and in the present study indicate that $\mathrm{ADV}$ has remained endemic in the WB population in Poland for at least a dozen years. In Germany, this period was estimated at 23 years (25) and, in the USA, for as long as 32 years (28). Furthermore, it is evident that the WB population is still growing, not only in Europe, but also in the USA. This tendency will result in further spread of AD and an increase in WB infected with ADV (25). Taking into account the aforementioned spreading of $\mathrm{AD}$ among WB populations and the tremendous progress in the elimination of $\mathrm{AD}$, as well as its complete eradication from many European countries and the USA, the potential risk of $\mathrm{ADV}$ transmission from infected $\mathrm{WB}$ to susceptible farm animals has become a matter of growing concern (25).

Based on serological and molecular studies, it is suggested that ADV infection in DP and WB represents epidemiologically distinct infection cycles $(15,26,27$, $30)$. On the other hand, experimental investigations have shown that the risk of ADV transmission from $\mathrm{WB}$ to DP cannot be excluded, as infected WB can shed the virus in a sufficient amount to infect susceptible swine $(15,25)$. The earlier suggestion that the veneral route is the main one for ADV transmission among the WB population $(30,31)$ was verified recently, on the basis of the results of intensive experiments. It has been proven that veneral transmission of ADV is not the only one, but both veneral and oral/nasal shedding represent the two major routes of ADV transmission $(14,36)$.

Taking into account the aforementioned data on the one hand, and the reasonably high biosecurity level of commercial pig farms in agriculturally developed countries on the other, it seems that the risk of spill-over infection with ADV from WB to DP appears to be high only for backyard holdings or outdoor-reared swine $(6,14,25)$. Such cases are very rare and have only been documented in France and the Czech Republic (25). In 2003, however, Germany was declared an ADV-free country. In spite of a high seroprevalence of ADV, particularly in East Germany, no spill-over of this virus has been detected in DP $(10,24,27)$. A similar situation can be observed in Spain, where an average percentage of ADV-infected WB between 2000 and 2010 amounted 
to $49.6 \%$ and $\mathrm{ADV}$ seroprevalence among $\mathrm{DP}$, during intensive $\mathrm{AD}$ eradication, decreased from $70 \%$ in 2003 to $1.7 \%$ in 2010 (3). Similarly, Croatia, where the percentage of ADV seropositive WB increased from $28.1 \%$ during the hunting season $2005 / 2006$ to $57.4 \%$ in the hunting season 2009/2010, is officially AD free (29). In Austria, free of $\mathrm{AD}$ since 1997, the detected percentage of seroreagents amounted, on average, to $55.2 \%$ (37), in the Czech Republic - with the same ADfree status - $29.9 \%$ of ADV seropositive WB were found, and in Slovenia, free of AD since 2010, 26\%$45.1 \%$ of ADV seroreagents were recorded $(39,43,44)$. In France, free of $\mathrm{AD}$ (except for a few departments), WB infected with ADV were also found $(1,25)$.

In the USA, where $\mathrm{AD}$ eradication has been carried out for over 15 years (14), ADV is spreading uncontrollably among feral swine, including the population of these animals in such states as Nebraska (45) situated in the north, far away from their traditional, natural habitat in the southern part of the USA.

Overall, there has been a noticeable increase in the percentage of $\mathrm{ADV}$-infected $\mathrm{WB}$ in the past two decades, not only in Europe but also in the USA and many other countries, which might have been induced by the permanent increase in the populations of these wild animals (25). In view of this situation, the constant monitoring of $\mathrm{AD}$ among $\mathrm{WB}$ populations seems to be a necessity $(34,42)$. It is especially important in the countries that are close to completing their $\mathrm{AD}$ eradication programmes, or which are officially recognised as AD-free (25). There are two approaches on how such a serosurvey should be performed. One of them is based on monitoring at bi- or even triennial intervals, during which sufficient information on the spread and dynamics of ADV infection in WB populations would be obtained (25). Such serosurvey has been conducted in East Germany over several years with invaluable results $(27,41)$. Of course, for statistical evaluation, the following should be considered: sample size, size of the area of study, and practical aspects (i.e. the feasibility of sample collection) and the detection of other diseases (25).

The second approach assumes that populations of $\mathrm{WB}$, already known to be infected with $\mathrm{ADV}$, are of no interest, because of the endemic circulation of this virus, which could last as long as 32 years (7, 28). Alternatively, special attention should be devoted to WB populations with an unknown epizootic status regarding AD (7).

In conclusion, it should be stated that the presented studies to a great extent fall within the first approach mentioned above. The results of this study show a considerable increase in the percentage of WB infected with ADV, compared to the results of the survey conducted during 1997 to $2000(20,40)$. Over the last dozen years, the ADV infection rate has doubled in Polish WB population. Moreover, ADV seropositive WB have been detected across the whole country. This unequivocally indicates the necessity for the continuation of this kind of serosurvey, at bi- or even triennial intervals, aiming to assess the spread and dynamics of ADV infection among WB. The issue is especially important in the present situation, when Poland is applying to be officially recognised by the EU Commission as an AD-free country.

Conflict of Interests Statement: The authors declare that there is no conflict of interests regarding the publication of this article.

Financial Disclosure Statement: This study was supported by the National Centre of Research and Development (Poland) grant no. 12-0126-10 and by project no. $\mathrm{S} / 215$, "The role of wild boar in the epidemiology of Aujeszky's disease", conducted within the statutory activity of the National Veterinary Research Institute in Pulawy, Poland.

Animal Rights Statement: None required.

Acknowledgements: The authors would like to thank Ewa Piekutowska-Nóżka and Stanisława Boreczek for their skilled technical assistance.

\section{References}

1. Albina E., Mesplède A., Chenut G., Le Potier M.F., Bourbao G., Le Gal S., Leforban Y.: A serological survey on classical swine fever (CSF), Aujeszky's disease (AD), and porcine reproductive and respiratory syndrome (PRRS) virus infections in French wild boars from 1991 to 1998 . Vet Microbiol 2000, 77, 43-57.

2. Baradel J.M., Barrat J., Blancou J., Boutin J.M., Chastel C., Dannacher G., Delorme D., Gerard Y., Gourreau J.M., Kihm U., Larenaudie B., Le Goff C., Pastoret P.-P., Perreau P., Schwers A., Thiry E., Trap D., Uilenberg G., Vannier P.: Results of a serological survey of wild mammals in France. Rev Sci Tech Off Int Epiz 1988, 7, 873-883.

3. Boadella M., Gortázar C., Vicente J., Ruiz-Fons F.: Wild boar: an increasing concern for Aujeszky's disease control in pigs? BMC Vet Res 2012, 8, 7.

4. Ciacci-Zanella J.R., Zanella E.L., Simon N.L., Schiochet M.F., Schaefer R., Silveira S., Piovezan U., Juliano R.S., Okino C.H.: Investigation of pseudorabies virus infection in Brazilian feral swine populations. $22^{\text {nd }}$ International Pig Veterinary Society Congress, Jeju, Korea 2012, p. 456.

5. Commission Decision 2008/185/EC of 21 February 2008 on additional guarantees in intra-Community trade of pigs relating to Aujeszky's disease and criteria to provide information on this disease. OJ L 59, 4.3.2008, p. 19.

6. Corn J.L., Cumbee J.C., Barfoot R., Erickson G.A.: Pathogen exposure in feral swine populations geographically associated with high densities of transitional swine premises and commercial swine production. J Wildl Dis 2009, 45, 713-721.

7. Corn J.L., Stallknecht D.E., Mechlin N.M., Luttrell M.P., Fischer J.R.: Persistence of pseudorabies in feral swine populations. J Wildl Dis 2004, 40, 307-310.

8. Cromwijk W.A.: Serological studies in wild boars in the Veluwe area. Tijdschr Diergeneeskd 1995, 120, 364-365.

9. Davison A.J.: Herpesvirus systematics. Vet Microbiol 2010, 143, 52-69.

10. Denzin N., Borgwardt J., Freuling C., Müller T.: Spatio-temporal analysis of the progression of Aujeszky's disease virus infection 
in wild boar of Saxony-Anhalt, Germany. Geospatial Health 2013, 8, 203-213.

11. Elbers A.R., Dekkers L.J., van der Giessen J.W.: Serosurveillance of wild boar in the Netherlands, 1996-1999. Rev Sci Tech 2000, 19, 848-854.

12. Forestry 2014. Central Statistical Office, Warsaw 2014, pp. 161-162.

13. Gagrcin M., Circovic D., Orliae C.D.: Wild pigs as a reservoir of Aujeszky's disease. Microbiologia, Belgrad 1989, 26, 149-152.

14. Hahn E.C., Fadl-Alla B., Lichtensteiger C.A.: Variation of Aujeszky's disease viruses in wild swine in USA. Vet Microbiol 2010, 143, 45-51.

15. Hahn E.C., Page G.R., Hahn P.S., Gillis K.D., Romero C., Annelli J.A., Gibbs E.P.J.: Mechanisms of transmission of Aujeszky's disease virus originating from feral swine in the USA. Vet Microbiol 1997, 55, 123-130.

16. Kim J., Lim S.I., Han G.H., Song J.Y., Lee K.W., Hyun B.H.: Serological survey of Aujeszky's disease in South Korean wild boar (Sus scrofa) population. 22 ${ }^{\text {nd }}$ International Pig Veterinary Society Congress, Jeju, Korea 2012, p. 463.

17. Lari A., Lorenzi D., Nigrelli D., Brocchi E., Faccini S., Poli A.: Pseudorabies virus in European wild boar from Central Italy. J Wildl Dis 2006, 42, 319-324.

18. Leuenberger R., Boujon P., Thür B., Miserez R., GarinBastuji B.: Rüfenacht J., Stärk K.D.C.: Prevalence of classical swine fever, Aujeszky's disease, and brucellosis in a population of wild boar in Switzerland. Vet Rec 2007, 160, 362-368.

19. Lipowski A., Pejsak Z.: Aujeszky's disease - a potentially dangerous barrier in international trade of pigs. Życie Wet 2001, 76, 76-79.

20. Lipowski A., Pejsak Z.: Antibody prevalence of pseudorabies virus in feral pigs in Poland. $17^{\text {th }}$ International Pig Veterinary Society Congress, Ames, USA 2002, vol. 2, p. 223.

21. Mettenleiter T.C., Ehlers B., Müller T., Yoon K.J., Teifke J.P.: Herpesviruses. In: Diseases of Swine, edited by J.J. Zimmerman, L.A. Karriker, A. Ramirez, K.J. Schwartz, G. Stevenson, Wiley Blackwell, Ames, USA, 2012, pp. 421-446.

22. Regulation of Polish Government of 19 March 2008 concerning introducing Aujeszky's disease eradication programme. Journal of Laws of the Republic of Poland, 2008, No. 64, item 397.

23. Montagnaro S., Sasso S., De Martino L., Longo M., Iovane V., Ghiurmino G., Pisanelli D., Nava D., Baldi L., Pagnini U.: Prevalence of antibodies to selected viral and bacterial pathogens on wild boar (Sus scrofa) in Campania Region, Italy. J Wildl Dis 2010, 46, 316-319.

24. Müller T., Bätza H.-J., Schlüter H., Conraths F.J., Mettenleiter T.C.: Eradication of Aujeszky's disease in Germany. J Vet Med B 2003, 50, 207-213.

25. Müller T., Hahn E.C., Tottenwitz F., Kramer M., Klupp B.G., Mettenleiter T.C., Freuling C.: Pseudorabies virus in wild swine: a global perspective. Arch Virol 2011, 156, 1691-1705.

26. Müller T., Klupp B.G., Freuling C., Hoffmann B., Mojcicz M., Capua I., Palfi V., Toma B., Lutz W., Ruiz-Fon F., Gortárzar C., Hlinak A., Schaarschmidt U., Zimmer K., Conraths F.J., Hahn E.C., Mettenleiter T.C.: Characterization of pseudorabies virus of wild boar origin from Europe. Epidemiol Infect 2010, 138, 1590-1600.

27. Pannwitz G., Freuling C., Denzin N., Schaarschmidt U., Nieper H., Hlinak A., Burkhardt S., Klopries M., Dedek J., Hoffmann L., Kramer M., Selhorst T., Conraths F.J., Mettenleiter T., Müller T.: A long-term serological survey on Aujeszky's disease virus infections in wild boar in East Germany. Epidemiol Infect 2012, 140, 348-358.

28. Pedersen K., Bevins S.N., Baroch J.A., Cumbee J.C., Chandler S.C., Woodruff B.S., Bigelow T.T., DeLiberto T.J.: Pseudorabies in feral swine in the United States, 2009-2012. J Wildl Dis 2013, 49, 709-713.

29. Roic B., Jemersic L., Terzic S., Keros T., Balatinec J., Florijancic T.: Prevalence of antibodies to selected viral pathogens in wild boars (Sus scrofa) in Croatia in 2005-06 and 2009-10. J Wildl Dis 2012, 48, 131-137.

30. Romero C.H., Meade P., Santagata J., Gillis K., Lollis G., Hahn E.C., Gibbs E.P.J.: Genital infection and transmission of pseudorabies virus in feral swine in Florida, USA. Vet Microbiol 1997, 55, 131-139.

31. Romero C.H., Meade P.N., Shultz J.E., Chung H.Y., Gibbs E.P., Hahn E.C., Lollis G.: Veneral transmission of pseudorabies viruses indigenous to feral swine. J Wildl Dis 2001, 37, 289-296.

32. Ruiz-Fons F. Vicente J., Vidal D., Höfle U., Villanúa D., Gauss C., Segalés J., Almería S., Montoro V., Gortázar C.: Seroprevalence of six reproductive pathogens in European wild boar (Sus scrofa) from Spain: the effect on wild boar female reproductive performance. Theriogenology 2006, 65, 731-743.

33. Ruiz-Fons F., Vidal D., Höfle U., Vicente J., Gortázar C.: Aujeszky's disease virus infection patterns in European wild boar. Vet Microbiol 2007, 120, 241-250.

34. Sattler T., Sailer E., Wodak E., Schmoll F.: Serological detection of emerging viral infections in wild boars from different hunting regions of Southern Germany. Tierärztl Prax 2012, 40, 27-32.

35. Sedlak K., Bartova E., Machova J.: Antibodies to selected viral disease agents in wild boars from the Czech Republic. J Wildl Dis 2008, 44, 777-780.

36. Smith G.: Preferential sexual transmission of pseudorabies virus in feral swine populations may not account for observed seroprevalence in the USA. Prev Vet Med 2012, 103, 145-156.

37. Steinrigl A., Revilla-Fernández S., Kolodziejek J., Wodak E., Bagó Z., Nowotny N., Schmoll F., Köfer J.: Detection and molecular characterization of Suid herpesvirus type 1 in Austrian wild boar and hunting dogs. Vet Microbiol 2012, 157, 276-284.

38. Steinrigl A., Revilla-Fernández S., Wodak E., Bagó Z., Schmoll F.: Diagnostic aspects of Suid herpesvirus 1 infection in wild boar. $2^{\text {nd }}$ European Association of Veterinary Laboratory Diagnosticians Congress, Kazimierz Dolny, Poland 2012, S3-O-10.

39. Štukelj M., Toplak I., Vengušt G.: Prevalence of antibodies against selected pathogens in wild boars (Sus scrofa) in Slovenia. Slov Vet Res 2014, 51, 21-28.

40. Szweda W., Lipowski A., Ciecierski H., Pirus T.: Evaluation of the level of infection with Herpesvirus suis 1 in wild boar in Olsztyn province, Poland. $15^{\text {th }}$ International Pig Veterinary Society Congress, Birmingham, U.K. 1998, p. 344.

41. Thulke H.H., Selhorst T., Müller T.: Pseudorabies virus infections in wild boar: data visualization as an aid to understanding disease dynamics. Prev Vet Med 2005, 68, 35-48.

42. Van der Leek M.L., Gibbs E.P.J.: Aujeszky's disease virus infections in wild swine in the USA. $12^{\text {th }}$ International Pig Veterinary Society Congress, the Hague, the Netherlands 1992, p. 86.

43. Vengust G., Valencak Z., Bidovec A.: Presence of antibodies against Aujeszky's disease virus in wild boar (Sus scrofa) in Slovenia. J Wildl Dis 2005, 41, 800-802.

44. Vengust G., Valencak Z., Bidovec A.: A serological survey of selected pathogens in wild boar in Slovenia. J Vet Med B 2006, $53,24-27$.

45. Vicente J., Ruiz-Fons F., Vidal D., Höfle U., Acevedo P., Villanúa D., Fernández-de-Mera I.G., Martín M.P., Gortázar C.: Serosurvey of Aujeszky's disease virus infection in European wild boar in Spain. Vet Rec 2005, 156, 408-412.

46. Wilson S., Doster A.R., Hoffman J.D., Hygnstrom S.E.: First record of pseudorabies in feral swine in Nebraska. J Wildl Dis 2009, 45, 874-876

47. Župančić Ž., Jukić B., Lojkić M., Čač Ž., Jemeršić L., Starešina V.: Prevalence of antibodies to classical swine fever, Aujeszky's disease, porcine reproductive and respiratory syndrome, and bovine viral diarrhea viruses in wild boars in Croatia. J Vet Med B 2002, 49, 253-256. 